\title{
Analyzing Indonesian Online Newspaper Headlines Using Lexical Functional Grammar
}

\author{
Annisa Ratna Purwanti \\ Diponegoro University \\ niratpur@windowslive.com
}

\begin{abstract}
How to cite (in APA Style): Purwanti, A.R. (2019). Analyzing Indonesian Online Newspaper Headlines Using Lexical Functional Grammar. Jurnal Pendidikan Bahasa dan Sastra, 19(2), 150-163 DOI: https://doi.org/10.17509/bs_jpbsp.v19i2.24782
\end{abstract}

Article History: Received (6 august 2019); Revised (21 September 2019); Accepted (1 October 2019). Journal homepage: http://ejournal.upi.edu./index.php/BS_JPBSP

\begin{abstract}
Newspaper headlines have different characteristics to daily or ordinary sentences. They are constructed in such a way to make the readers interested to read the whole news articles. As a result, the syntax for headlines is different. The omission of some parts of the sentences in the headlines are one of the strategies held by the writers to construct effiecient and effective headlines due to the limited space given. Therefore, this qualitative study aims to highlight the syntactical structures of headlines, and also to explain the functions of the words found in the headlines using Lexical Functional Grammar (LFG). In the analysis, LFG has two structures; c-structure and f-structure. C-structure is represented by X-bar in the form of tree diagram, while f-structure is represented by a matrix and followed by a lexical entry. The findings show that there are several characteristics of several famous Indonesian online newspaper headlines which can be a generic structure of a headline. The use of X-COMP, XADJ, and OBL $\theta$ tends often to occur in the Indonesian headlines. By implementing these functions, it can be a strategy for the writers in generating catchy and efficient headlines.
\end{abstract}

Keywords: headlines; Lexical Functional Grammar (LFG); c-structure; f-structure; X-bar

\section{Analisis Tajuk Utama pada Surat Kabar Daring Indonesia menggunakan Lexical Functional Grammar}

\begin{abstract}
Abstrak: Berita utama atau tajuk surat kabar memiliki karakteristik yang berbeda dengan kalimat biasa atau sehari-hari. Ia disusun sedemikian rupa untuk membuat para pembaca tertarik membaca seluruh artikel berita. Akibatnya, sintaksis untuk tajuk utama berita berbeda. Penghilangan beberapa bagian kalimat dalam tajuk utama adalah salah satu strategi yang dipegang oleh penulis untuk membuat tajuk utama yang efisien dan efektif karena terbatasnya ruang yang diberikan. Oleh karena itu, penelitian kualitatif ini bertujuan untuk menyoroti struktur sintaksis dari tajuk utama, dan juga untuk menjelaskan fungsi kata-kata yang ditemukan dalam tajuk utama menggunakan Lexical Functional Grammar (LFG). Dalam analisis, LFG memiliki dua struktur; c-struktur dan f-struktur. C-struktur diwakili oleh X-bar dalam bentuk diagram pohon, sedangkan f-struktur diwakili oleh matriks dan diikuti oleh entri leksikal. Temuan menunjukkan bahwa ada beberapa karakteristik dari beberapa berita utama surat kabar daring terkenal Indonesia yang dapat menjadi struktur generik dari tajuk utama. Penggunaan X-COMP, X-ADJ, dan OBLO cenderung sering terjadi di tajuk utama Indonesia. Dengan mengimplementasikan fungsi-fungsi tersebut, hal ini dapat menjadi strategi bagi para penulis dalam menghasilkan berita utama yang menarik dan efisien.
\end{abstract}

Kata kunci: berita utama; Lexical Functional Grammar (LFG); c-struktur; f-struktur; X-bar 


\section{INTRODUCTION}

Newspaper headlines are the one of the interesting parts of news reports. Swan in Practical English Usage (2005) defines headlines are the short title above the news reports. Ogunsiji (1989: 97) states that headlines are arranged in a way that can reveal fast the social, cultural, economic and political issues unfolding in a society at any given time. They are designed to attract the readers by using catchy or interesting words or phrases. If someone reads a newspaper or online news, they tend to look at the headlines first. If they think it is interesting, then they continue to read the articles. To make them catchy, the structures of headlines seem to be different than ordinary sentences. For instance, omitting the articles, using $\mathrm{x}$-comp (deleting the subject or the participant), and sometimes headlines can consist of phrases only.

Investigating newspaper headlines might be an important phenomenon. They can be significance as they provide models of linguistic behaviors and general features of the language in a community and make them apparent to modern readers (Alamoudi, 2017). The readers often get influenced by the particular linguistic structures constructed in headlines. Moreover, Ehinani (2014) states that it may be considered that factors such as house style of the publishing industry, the reasons of space and the intention to inform quickly about the facts influence the way linguistic expressions are designed with a deliberate reduction of the full syntax of the structures. Therefore, the structures of headlines may vary according those factors. However, if we examine closely, there will be general structures of headlines. Some structures will be acceptable, while others are not.

The structures of headlines are categorized into syntax study. Syntax is a part of linguistics which consisted of the principles and processes by which sentences are constructed in particular languages. One of the tools for modelling syntax is X-Bar Theory. It parses the sentences by determining the relationships between word classes and analyzing how to group those words into phrases. By establishing X-Bar Theory, we can decide the head of the phrase, the complement, and the adjunct. X-Bar is represented in a syntax tree. Syntax trees are unambiguous because they clearly represent groupings of words (as constituency).

However, in the headlines, sometimes the journalists omit the subject or object. It cannot be analyzed in detail by $\mathrm{X}$-Bar, it needs further analysis by applying LFG. The researcher uses Lexical Functional Grammar (LFG) to analyze the syntactical structure of the headlines. LFG is a theory of generative grammar, in the sense of Chomsky's school. It aims specify a grammar that models the speaker's knowledge explicitly and which is distinct from the computational mechanisms that constitute the language processor (Kaplan \& Bresnan, 1982).

Several studies have been conducted on analyzing news headlines. Nevertheless, those studies focus on the structural ambiguity of news headlines, not the syntactical structures. X-bar theory is usually used fror analysing ambiguity in a sentence. To begin with, Tiono (2003) investigates the different linguistic choices and structures used in the headlines found inThe Jakarta Post and Indonesian Daily published in 20th and 21st June 2001. She compares the headlines with the same topic from both newspapers and identified the linguistic choice and structure. She examines the grammar and the linguistic choice by using Leech's language function theory. Then, tree diagrams are used to analyze the linguistic structure. In conclusion, she saysthat both newspapers used simple future tense with the deletion of the verb. They also have differences in the linguistic choices.

Another previous study is conducted by Elmawati (2013), she aims to highlight the structural ambiguity of headlines complied by Department of 
Languages, Cultures and Linguistics Bucknell University using the X-bar theory.She finds that ambiguity occurs in lexical level in which one word can be interpreted as having several different meanings. The factors that create ambiguity in a written text are the lack of tone, stress and pitch. Moreover, she describes three main factors causing structural ambiguity. The factors are the differences of syntactic category, placement of prepositional phrase that functions as an adjunct and sub categorization of verbs. The difference of syntactic category makes the headlines to be structurally ambiguous because a word may have different categories depending on the following or preceeding words. The next factor is the placement of prepositional phrase which is usually located in the final position. It impactsthe structural ambiguity of a sentence. It can be the adjunct of a noun phrase or the adjunct of a verb phrase. Sub categorization of verbs also one of the factors which makes structural ambiguity. Transitive verbs can be followed by only a direct object or a direct object and an infinitive phrase.

Structural ambiguity is not only investigated in Indonesia, but also in Nigeria. Ehineni (2014) analyzesNigerian English newspaper headlines from a syntactic perspective in terms of lexical and functional heads. He highlights the lexical and functional heads of newspaper headlines found in Nigerian newspaper. The researcher applies the X-bar theory of Transformational Generative Grammar to syntactically analyze the data. He finds that both lexical and functional heads are projected in Nigerian newspaper headlines. Nevertheless, their representation depends on the syntactic configuration of the headlines. Sentence type headlines have more heads than phrasal headlines. While both heads occur in the headlines, lexical heads have more projection than functional heads.

Based on the phenomenon and explanation above, the writer is interested to introduce different kind of Indonesian online newspaper headlines which usedIndonesia language. Some previous studies mentioned above are conducted in Indonesia, but they focus on English language newspaper which issued in Indonesia. They also use only X-bar theory, in this study, I would like to extend those studies into the study of LFG. Hence, this research tries to figure out the generic structures of headlines found in Indonesian online newspaper and also analyze the syntactical structures using LFG.

The theory used to identify the syntactic structures of Indonesian online newspaper headlines is Lexical Functional Grammar (LFG). LFG was developed in the 1970's by Joan Bresnan, a linguist at MIT, and Ron Kaplan, a psychologist at Harvard. Since its foundation, the theory has been applied to numerous new areas, undergoing some modification in the process, and has incorporated insights from a variety of morphological, syntactic, and semantic theories. It is a lexical approach, meaning that lexical items or words are as crucial as syntactic structures in encoding grammatical information. Dalrymple (2001) states that LFG considers language is best described and modeled by parallel structures representing different facets of linguistic organization and information, related to one another by means of functional constraints.

Asudeh and Toivonan (2009) describes that LFG consists of two syntactic structures: constituent structure (c-structure; represented by X-bar theory of Generative Grammar and tree diagrams) and functional structure (f-structure). While Subiyanto (2011) adds one more structure, that is argument structure.

C-structures are represented as phrase structure trees and model precedence (word order), dominance, constituency and syntactic categories. Feature structures represent F-structures. An $\mathrm{f}$-structure is a finite set of attributevalue pairs, such that an attribute is a symbol and its value is: a) a symbol (e.g., 
SINGULAR or + ); b) a semantic form (a potentially complex symbol in single quotes); c) a set; or d) an f-structure. The fstructure of a sentence contains the grammatical functions that the head verb subcategorizes for (SUBJECT, OBJECT, etc.) and also represents a range of morphosyntactic information, such as case, agreement features, tense and aspect. F- structure is the level at which abstract syntactic relations are captured, such as agreement, control and raising, binding, and unbounded dependencies. The following is an example of analyzing a sentence "The kid is eating a cake" using cand f-structure taken from Asudeh and Toivonan (2009: 2).

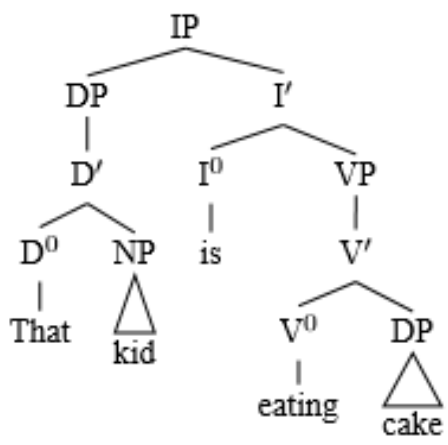

Figure 1. C-structure of a sentence

$$
\left[\begin{array}{ll}
\text { PRED } & \text { 'eat/SUBJ, OBJ }\rangle \\
\text { SUBJ } & {\left[\begin{array}{ll}
\text { PRED } & \text { 'kid' } \\
\text { DEIXIS } & \text { DISTAL } \\
\text { DEFINITE } & + \\
\text { NUMBER } & \text { SINGULAR } \\
\text { PERSON } & 3
\end{array}\right]} \\
\text { OBJ } & {\left[\begin{array}{ll}
\text { PRED } & \text { 'cake' } \\
\text { NUMBER } & \text { SINGULAR } \\
\text { PERSON } & 3
\end{array}\right]} \\
\text { TENSE } & \text { PRESENT } \\
\text { ASPECT } & \text { PROGRESSIVE } \\
\text { PARTICIPLE } & \text { PRESENT }
\end{array}\right]
$$

Figure 2. Matrix 1. F-structure of a sentence

Based on the analysis, c-structure is a surface phrase structure models the syntactic information, such as word order and constituency whereas f-structure models are more abstract syntactic information and relations. C-structures can be widely varied between languages, but fstructural remains relatively constant across languages. It is thus at $\mathrm{f}$-structure that we observe many cross-linguistic universals. It is also possible that there are more than one c-structures in analyzing a sentence, for instance, in analyzing an ambiguous sentence. Subiyanto (2011) adds that the theory of LFG defines $f$ structure and c-structure as independent, but they are actually mutually constraining levels of representation.

In LFG, there are Governable Grammatical Functions (GGF). They are reflection of predicate-argument relations, and a central purpose of $f$-structure is to capture these relations (Asudeh \& Toivonan, 2009). GGF consists of: 
1. Subject (SUBJ)

2. Object (OBJ)

Object refers to the first object: Harry gives some money.

$$
\text { SUBJ OBJ }
$$

3. $\operatorname{Object} \theta(\mathrm{OBJ} \theta)$

Object $\theta$ is a second object or indirect object. It occurs after object.

Harry gives Taylor some money

SUBJ OBJ OBJ $\theta$

4. Oblique (OBL)

It is an agent in passive voice.

The money was given (by Harry). "By Harry" is an oblique and it can be omitted.

5. Complement (COMP)

It refers to a closed complement which has its own subject. In simple words, we can say COMP has subject and predicate (i.e verb).

Gigi made a cake.

6. X-COMP

It is an open predicate complement. It means an argument with no overt subject of predication. Bella told Selena to sing. "To sing" has an overt subject (hidden).

7. Adjunct (ADJ)

It is a modifier and a non-argument.

Gigi made a yummy cake.

8. X-ADJ

It has the same form like X-COMP. It means it has something hidden. It is usually defined as an open predicate adjunct.

Being asked by Bella, Gigi made a yummy cake.

9. Specifier (SPEC)

It is a possessor or quantificational determiner phrase.

Selena's dress' colour is peach.

Furthermore, headlines usually consist of four or five words which functions to attract the interest of the reader by telling them what the news is about, in a short and interesting way. Swan (2005) defines that headlines are the short titles above newspaper reports which sometimes can be difficult to understand, due to the fact that they are written in a special style. Moreover, McArthur in Mozūraityté (2015) describes that headlinese is the language of headlines which is affected by the constraints on space. Newspaper headlines or headlinese may be varied around the world. The construction depends on many factors. Despite its variety, some generalization can be made. The following is some structures of headlinese in general. A classification of headlinese is explained in Mozūraityte (2015). She classifies the following linguistic features as typical of headlines in English newspapers:

1. Full declarative sentences (e.g., Allies Now Look to London (The Times)).

2. Interrogative sentences (e.g., Do you love war? (Daily World)).

3. Nominative sentences (e.g., Gloomy Sunday (The Guardian)). 
4. Elliptical sentences:

- with an auxiliary verb omitted (e.g., Yachtsman spotted (Morning Star));

- with the subject omitted (e.g., Will win (Morning Star));

- with the subject and part of the predicate omitted (e.g., Still in danger (The Guardian)).

5. Sentences with articles omitted (e.g., Blaze kills 15 at Party (Morning Star)).

6. Phrases with verbal-infinitive, participial and gerundial (e.g., To get US aid' (Morning Star), Keeping Prices Down (The Times)).

7. Questions in the form of statement (e.g., The worse the better? (Daily World)).

8. Complex sentences (e.g., Army Says It Gave LSD to Unknown GIs (International Herald Tribune)).

9. Headlines including direct speech:

- introduced by a full sentence (e.g., 'Tell Margaret I love her' he said and then he died (Sunday Express));

- introduced elliptically (e.g., New rate support system best in Europe Minister (The Guardian)).

Those features more or less are similar in Indonesian online newspaper headlines. The feature named elliptical sentences is categorized in X-COMP or X ADJ. Most of the headlines are not in sentence forms, but in phrase forms. There are 6 phrases category in the TGG. Those are Determiner Phrase (DP), Inflectional Phrase (IP), Verb Phrase (VP), Noun Phrase (NP), Adjective Phrase (AdjP), Adverb Phrase (AP), Prepositional Phrase (PP), and Complement Phrase (CP). To classify what phrase a word/ words belong, determine the first word's category. For instance, "the glasses", in traditional grammar, it will be a NP. While in TGG (Transformational-generative grammar)), it is a DP because it starts with a determiner. Moreover, a word also can be categorized into a phrase. Therefore, this phrase categorization is going to be discussed in this paper.

Based on the phenomenon and explanation above, the writer is interested to introduce different kind of Indonesian online newspaper headlines which used Indonesian language. Some previous studies mentioned above are conducted in Indonesia, but they focus on English language newspaper which issued in Indonesia. They also use only X-bar theory, in this study, I would like to extend those studies into the study of LFG. Hence, this research tries to figure out the generic structures of headlines found in Indonesian online newspaper and also analyze the syntactical structures using LFG.

\section{METHOD}

In this study, the resarcher will use an observation method with note taking technique to get the data from several online newspapers in Indonesia, like bbc.com/indonesia, detik.com, msn.com/id-id, and tempo.co published in November and December 2017. This research is established under the qualitative approach. The headlines are listed below:

1. Mengungkap Isi Perut Tentara Korea yang Penub dengan Cacing

2. Berebut Pucuk Beringin Usai Setya Novanto 'Game Over'

3. Sri Mulyani Terbitkan Aturan Hapus Denda Pajak 200 Persen

4. Agung Laksono Minta Novanto Legawa Mundur dari Jabatan Ketua DPR

5. Pertumbuban Ekonomi hanya 2,41 persen, Kepri genjot seketor pariwisata.

6. Bersib dari Longsoran, Rel KA Jalur Selatan Dinyatakan Aman Dilintasi.

7. Penghuni Rusun Daan Mogot 
Jurnal Pendidikan Bahasa dan Sastra, Volume 19, Nomor 2, Oktober 2019, pp. 159 - 163

Resah Dengar Program Pangan Murah Akan Dihapus.

8. Daerah Dipastikan Tidak Bisa Terbitkean SKT Ormas.

9. Ujung Kebidupan Para Penderita AIDS 'generasi pertama' di sebuah bangsal London.

10. Tercecer di GP Meksiko, tapi Lewis Hamilton jadi Juara Formula 1 Musim 2017.

11. Kiper Choirul Huda meninggal dunia setelab benturan dengan sesama pemain.

12. Di balik perang retorika AS-Korea Utara.

13. Semenanjung Korea semakin memanas.

14. TKW ilegal dari Indonesia masib didatangkan ke Suriah.

15. Jawaban Jokowi soal Pergantian Panglima

16. Rumah DP O Rupiah Ground Breaking Januari 2018.

17. Di Indonesia Penelitiannya Ditolak, Siswa Yogya Diundang Google.

18. Jadi Jurkam Khofifah-Emil di Jatim, AHY akan Terjun ke Lapangan.

19. Ditanya soal Pilkada Jatim, Khofifab Ungkap Pesan Jokowi.

20. Tak bisa berdagang di trotoar, pengadu mengadu ke Anies.

21. Dampingi Khofifah, Emil Dardak akan dipecat PDIP.

22. Tenggelam di danau galian pasir, sopir truk di Banjarnegara tewas.

Each of the headlines was categorized into a phrase they belong to according to TGG (Transformationalgenerative grammar). Then, they were analyzed using LFG. C-structure (represented by X-bar) used to reveal and explain the structures of headlines, while F-structure (represented by a matrix) is used to describe the function of each lexical. By analyzing using f-structure, we can know whether the phrases have COMP, X-COMP, ADJ, X-ADJ and other functions. Since this study emphasizes on the syntactic analysis to explore the structures, this study is qualitative study.

\section{RESULTS AND DISCUSSION Syntactical Structure of the Headlines}

Headlines are usually arranged in a sensational manner in order to arouse the reader's curiosity. However, in this study, we do not discuss the meaning as it is semantics area. The another way to make a sensational effect is by modifying syntactical structures. The data was analyzed and categorized into what the dominant structures they were. From the data, I found that those headlines have their own uniqueness. They were constructed in a 'special' way to attract the readers' interest at the first sight. Hence, the words found in the headlines are usually short and less different forms with the ordinary sentences.

The tendency of Indonesian online newspaper headlines are in the forms of XCOMP, X-ADJ, passive voice with OBL, passive voice, and active voice. Moreover, I found that newspaper headlines should explain some details related to "what, who, where, how". However, the "when" can be deleted as newspapers usually deal with daily events, also the "why" is explained rather in the text than in the headline. It can be seen that sometimes headlines do not follow this strict "what, who, where, how" rule. It depends on the perspectives that the writers want to highlight or what opinions they want the readers have. For instance, in the passive voice form, sometimes the agent is mentioned, and the other times are not. However, this categorization does not fully cover different linguistic features of headlines as the division is much more complex.

\section{$X-C O M P$}

$\mathrm{X}$-COMP means that in the sentence/phrase, there is a subject which hidden (or not mentioned). It is also knows as an open complement. In the theory (see Theoretical Framework about structure of headlines), it is said that the journalists tend to omit the subject. The articles (sebuah, seorang, seekor, dll) that usually preceded the subject and determiners (ini, itu) are also tend to be 
omitted. I only list some examples of headlines found containing X-COMP, while actually this form is the most used by the headlines.

1. [seseorang] Mengungkap Isi Perut Tentara Korea yang Penuh dengan Cacing

2. [beberapa orang] [memperebutkan] Berebut Pucuk Beringin Usai Setya Novanto 'Game Over'
3. Agung Laksono Minta Novanto Legawa [dia]Mundur dari Jabatan Ketua DPR

I would like to analyze the sentence "Berebut Pucuk Beringin Usai Setya Novanto 'Game Over' using Cstructure and F-structure. For analyzing using F-structure, the Indonesian sentence must be translated into English, "Seize 'Pucuk Beringin' after Setya Novanto Game Over."

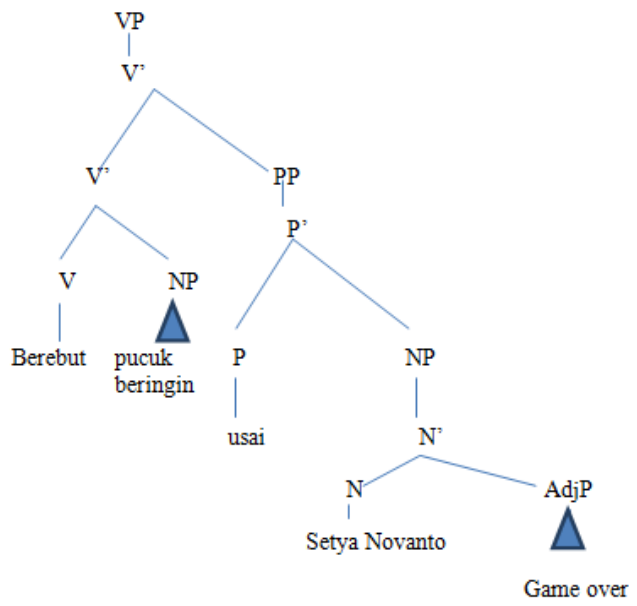

Figure 3. C-Structure of “Berebut Pucuk Beringin Usai Setya Novanto 'Game Over”.

The following figure presents the F-Structure of “(some people)Seize 'Pucuk Beringin' after Setya Novanto (is) Game Over." (Note: the bracket means those words should be put, but they do not show in the real sentence)

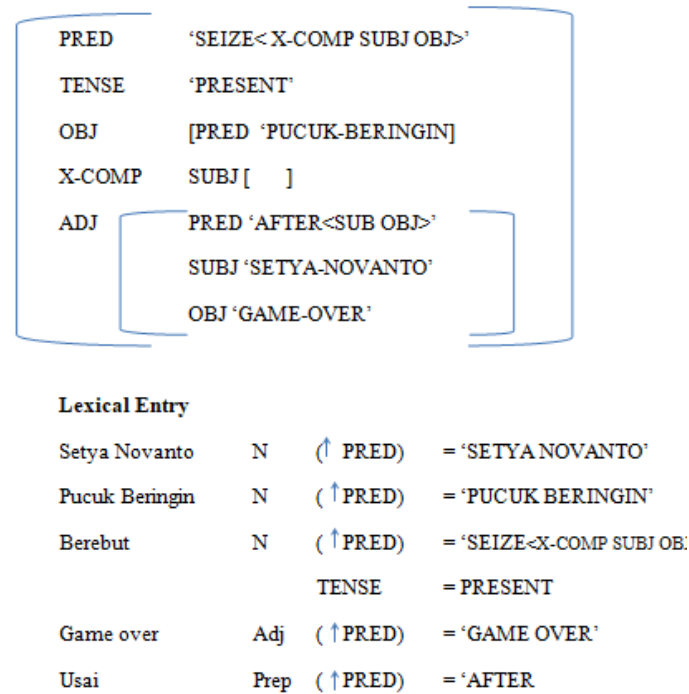

Figure 4. F-Structure of “(some people) Seize 'Pucuk Beringin’ after Setya Novanto (is) Game Over." 
The first analysis is the C-Structure. Before analyzing, I need to decide which one is the complement and the adjunct. I can determine that the complement is "pucuk beringin", the next phrase is the adjunct. In the C-structure, which adopts the X-bar theory, a maximal projection (NP, IP, DP, AdvP, AdjP, PP, VP, CP) must be projected through intermediate projection (X') to become a minimal projection (X). VP is the maximal projection to a verb. The node $\mathrm{V}^{\prime}$ (V-bar) is an intermediate projection, which can be expanded to V and NP. In Indonesian, the node "I" can be filled with a modal or an auxiliary verb, although in this sentence there is no inflectional because it is merged with the verb. In the C-structure above, the bracket means something is missing or not exists. For instance, NP in the beginning of the sentence is omitted although it should be exist.

At the first, the author has analyzed the complement and adjunct. Adjunct can emerge more than one in a sentence while complement does not have that pattern. The position of adjunct is under the $\mathrm{X}^{\prime}$ and near the $\mathrm{X}$ ', while complement is located under the X' and near the X. In the tree diagram above, $\mathrm{PP}$ as the adjunct is located under the V' and near the V'. This is how TGG differs from Traditional Grammar (TG). By using X-bar, we are able to determine the specifier, complement, and adjunct by their positions in the tree diagram.

However, X-bar only emphasizes on how the sentences or phrases constructed. It cannot explain why the subject is omitted in that sentence. Indonesian speakers also may recognize that the verb "berebut" cannot be followed by an object, because it is an intransitive. By using LFG, we can determine what functions of each lexical has. The concept is less different with TGG, although in LFG we still use $\mathrm{X}$-bar as the $\mathrm{C}$-structure. The difference lies in the function structure described by a matrix. LFG provides abstract functional organization of the sentence, explicitly representing syntactic predicate-argument structure and functional relations.

The problems were emerged when I analyzed the sentence using LFG. The subject-verb argument is one of the issues in that sentence. "Berebut" as a verb should have a subject, but there is an omission of it. It seems it does not need any subject whereas it is a verb, so it needs as subject. In LFG, it belongs to X-COMP where the subject is open (predicative) complement with subject externally controlled. In other words, the subject is being hidden. The next problem is "berebut" is an intransitive verb. It means it only need an argument and in a simple way, it cannot changed into passive. There is something mistaken here. That sentence actually needs two arguments, the subject and the object. Although the subject here is omitted, but it still means that the verb used should be a two-place verb. The choice of intransitive verb "berebut" rather than transitive verb "memperebutkan" may show one of the characteristics of a headline. It needs to be concise and as short as possible, but it still represents the whole article. That is the reason why the most of journalists use incorrect verbs or structures, they want to make their headlines are catchy.

Another fact is the writer uses a metaphorical form of "pucuk beringin". It does not mean of the real shoot of a banyan tree. However, this is semantic area, so I would rather not to discuss it. The function is to attract the readers' interest. I also did not translate it into English, because it refers to a proper name of an Indonesian political party (Golkar). Then, to combine two phrases, the writer put a preposition "usai" or after. The next phrase is a Noun Phrase because it is a proper name. In English syntax, there is a must to put a noun or gerund after the preposition "after". I can also construct a sentence after that preposition. So, the journalist cannot say "after read the book", but "after reading the book" or "after I read the book". A sentence usually consists 
of a subject and a verb or predicate. The phrase "usai Setya Novanto game over" in Indonesian syntax is correct. "Game-over" here is an adjective phrase which means someone has finished. In Indonesia, if the Indonesians want to say an adjective, it does not need preceded by any auxiliary. They will just simply say "aku sakit" (I sick). While in English, that construction will be incorrect. It needs an auxiliary, like is, am, or are. The symbol of a triangle means that there is a shortening of the projection process.

\section{$\boldsymbol{X}-\boldsymbol{A} \boldsymbol{D} \boldsymbol{J}$}

The concept of X-ADJ is similar to $\mathrm{X}$-COMP. X-ADJ and ADJ are nongovernable grammatical functions. It can modify the head in a flexible way. It differs from COMP and X-COMP where they have fixed emergence in the sentences. XADJ refers to ADJ which the subject is hidden. This function also tends to likely occur in the Indonesian online newspaper headlines. It is usually constructed to combine, compare, or contrast two phrases or sentences with the same subject. Therefore, the subject in the adjunct section is omitted. Headlines below are some examples of X-ADJ found in several online newspapers.

\section{Lewis Hamilton] Tercecer di GP Meksiko, tapi Lewis Hamilton}

[men]jadi Juara Formula 1 Musim 2017

2. Sseorang sopir truk] Tenggelam di danau galian pasir, [menyebabkan] [seorang] sopir truk di Banjarnegara tewas.

3. Ketika] [Sandi] [meN] Tunggu Kejelasan Sumber Waras, Sandi [meN] Janjikan Rumah Singgah untuk Penderita Kanker

4. Petugas Pemadam Kebakaran] [meN] Tarub Kamera di Toilet Wanita, [sehingga] Petugas Pemadam Kebakaran ditangkap

Similar to $\mathrm{X}-\mathrm{COM}$, in analyzing $\mathrm{X}$ ADJ using LFG, the first thing we do is determining which phrases categorized into COMP and ADJ because the first method in LFG is using $\mathrm{X}$-bar to represent the c-structure. The underlined phrases refer to adjunct. I would like to take an example to analyze, the sentence number 1, Tercecer di GP Meksiko, tapi Lewis Hamilton [men]jadi Juara Formula 1 Musim 2017or 'Left in Mexico GP, but Lewis Hamilton became winner of Formula 1 Season 2017. However, the word 'but' is a conjunction. According to Johannessen (1998) in his book "Coordination", he states that conjunction can be a head. So, there will be a CoP or Conjunction Phrase.

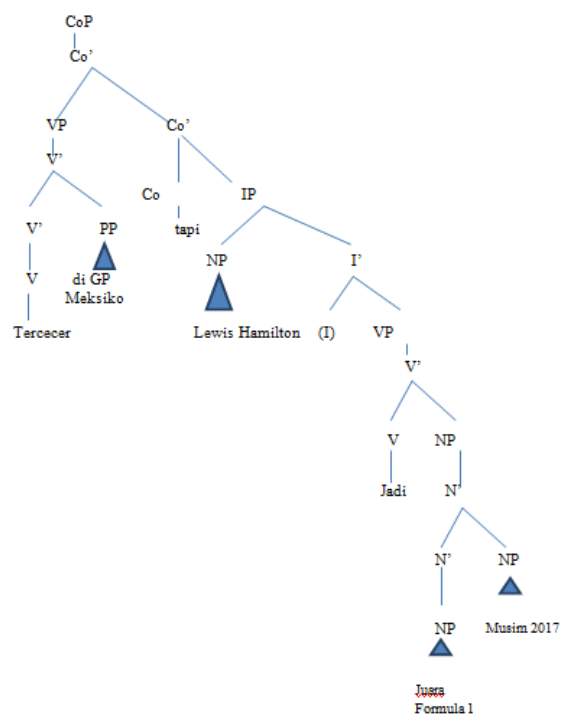


Jurnal Pendidikan Bahasa dan Sastra, Volume 19, Nomor 2, Oktober 2019, pp. 159 - 163

Figure 5. C-structure

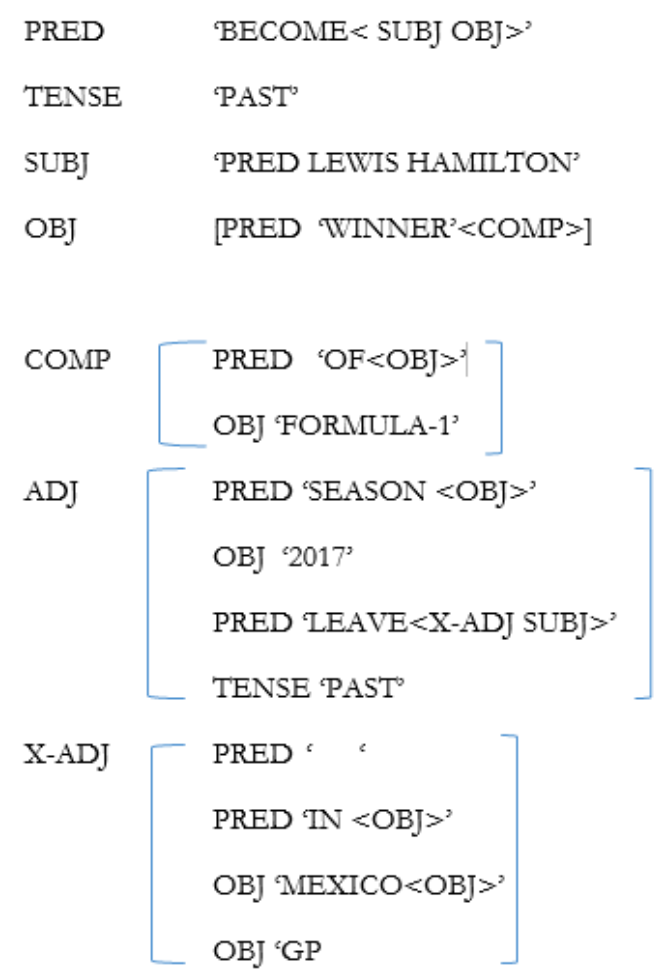

Figure 6. F-structure

\begin{tabular}{|c|c|c|c|}
\hline \multicolumn{4}{|l|}{ Lexical Entry } \\
\hline Lewis Hamilton & $\mathrm{N}$ & $(\uparrow$ PRED $)$ & $=$ 'LEWIS HAMILTON' \\
\hline Pemenang & $\mathrm{N}$ & ( $\left.{ }^{\uparrow} \mathrm{PRED}\right)$ & $=$ WINNER $<C O M P>>$ \\
\hline GP & $\mathrm{N}$ & $(\uparrow \mathrm{PRED})$ & $={ }^{\prime} \mathrm{G} \mathrm{P}^{\prime}$ \\
\hline Mexico & $\mathrm{N}$ & $(\uparrow \mathrm{PRED})$ & $=\mathrm{MEXICO}^{\prime}$ \\
\hline Formula 1 & $\mathrm{~N}$ & ( $\uparrow$ PRED) & $={ }^{'}$ FORMULA $1{ }^{\prime}$ \\
\hline Musim & $\mathrm{N}$ & $(\uparrow \mathrm{PRED})$ & $=' \mathrm{MUSIM}<\mathrm{OBJ}>\mathrm{\prime}$ \\
\hline 2017 & $\mathrm{~N}$ & $(\Uparrow \mathrm{PRED})$ & $={ }^{\prime} 2017$ ' \\
\hline \multirow[t]{2}{*}{ Jadi } & $\mathrm{V}$ & $(\uparrow \mathrm{PRED})$ & $=$ 'BECOME $<$ SUBJ OBJ $>$ ' \\
\hline & & TENSE & $=$ PAST \\
\hline \multirow[t]{2}{*}{ Tercecer } & $\mathrm{V}$ & $(\uparrow \mathrm{PRED})$ & $=$ LEAVE $<\mathrm{X}-\mathrm{ADJSUBJ}>$ ' \\
\hline & & TENSE & $=\mathrm{PAST}$ \\
\hline
\end{tabular}

The analysis first held to know the syntactical structure using c-structure. The structure can be considered to be a complex sentence. It has more than one predicate. Before we do the analysis, the step is deciding which phrases belong to complement or adjunct. In this sentence, I assume the adjunct is the first phrase (tercecer di GP Mexico), the phrase after the comma is the complement. I decide to 
categorize this sentence consists of a CoP (conjunction phrase), because it has the word 'but' that combines two phrases in contrasting. In constructing a tree diagram, I use the concept of $\mathrm{X}$-bar where adjunct must be put under the X' and near the X'. We must pay attention in locating the $\mathrm{X}^{\prime}$ and X or X", because it will change the structure of the sentence.

The CoP is extended into IP because the projection for "Lewis Hamilton jadi pemenang ..." is an inflectional. Although we cannot see the inflection there, it actually merges with the verb following it (jadi or became). IP is also the maximal projection for a sentence. Determiner Phrase emerges not only when there is a determiner (article, this, pronoun), but also in the noun. The word "juara" or winner is a noun. It must be derived from DP, D', NP, N', and N. The exception is for proper name, name of a place, and pronoun.

The following analysis is the analysis of f-structure. First, to omit the redundancy, the writer eliminated the subject for the adjunct. Hence, it is categorized into $\mathrm{X}$-ADJ. It has the same concept with X-COMP, but the subject is hidden in the complement, if X-ADJ, the subject is omitted in the adjunct. The writer eliminated it, so it shares the same subject in the second phrase (Lewis Hamilton). This pattern is often to occur in the Indonesian newspaper headlines. It usually occurs when there are two phrases or sentences need to combine or contrast by the writer. To make it efficient, as the principle of a headline is to make it as short as possible, but still conveys the whole articles and make the readers interested.

However, as an adjunct or X-ADJ, it is non-governable. It means it can attach to modify the head mostly everywhere in the sentence. For instance, for a normal sentence, we may write it "Lewis Hamilton tercecer di GP Meksiko tapi (men) jadi pemenang ...." Hence, adjunct is flexible and can appear more than one in the sentence.

\section{Phrase Categories of Newspaper Headlines}

By using LFG, it can be used to determine what phrase a sentence belongs to. I found that many headlines are not sentences, but only phrases. In this section, I would like to categorize what phrases usually headlines have. Moreover, based on the X-bar theory in categorizing phrases, I provide some of newspaper headlines found in several Indonesian online newspapers in the following text.

a. Determiner Phrase (DP)

1. 7 Kerajaan Bisnis Milik Gibran dan Kaesang

b. Inflectional Phrase (IP)

1. Agung Laksono Minta Novanto Legawa Mundur dari Jabatan Ketua DPR

2. ,Kepri genjot sek.tor pariwisata

3. ,Rel KA Jalur Selatan Dinyatakan Aman Dilintasi

4. Semenanjung Korea semakin memanas

5. Siswa Yogya Diundang Google

6. Khofifah Ungkap Pesan Jokowi

7. Jenderal Gatot Mutasi 85 Perwira TNI

c. Verb Phrase (VP)

1. Mengungkap Isi Perut Tentara Korea yang Penub dengan Cacing

2. Berebut Pucuk Beringin Usai Setya Novanto 'Game Over'

3. Ditanya soal Pilkada Jatim

4. Dampingi Khofifah,

5. Emil Dardak akan dipecat PDIP

d. Noun Phrase (NP)

1. Pertumbuban Ekonomi hanya 2,41 persen

2. Ujung Kebidupan Para Penderita AIDS 'generasi pertama' di sebuah bangsal London

3. Generasi tanpa asuban ibu

4. Jawaban Jokowi soal Pergantian Panglima TNI

5. Cerita Detik-Detike Pengangkapan 12 Aktivis di Kulon Progo Versi Warga

e. Adjective Phrase (AdjP)

1. Bersih dari Longsoran

2. Minim fasilitas, (keluarga tunggu pasien di lantai RS Polri) 
Jurnal Pendidikan Bahasa dan Sastra, Volume 19, Nomor 2, Oktober 2019, pp. 159 - 163

f. Adverb Phrase (AP) (the researcher has not found this phrase)

\section{g. Prepositional Phrase (PP)}

1. Di balik perang retorika AS-Korea Utara

2. Di Indonesia Penelitiannya Ditolak

3. Bila Anak tak Suka Sayuran

4. Saat Semua Menjadi Abli Hukum

5. Soal Peran Zumi Zola di Kasus Suap

\section{h. Complement Phrase (CP).}

1. Yang muda, yang berprestasi

From the list above, I cannot conclude that those phrases which best described the all headlines. However, I can say that those phrases are some of the most representing headlines in general because the choice of words/phrases the journalists use is so vary. Moreover, a journalist may not follow the rule. It depends on his intention and creativity. The most productive phrases are NP and IP, then followed by PP and VP. DP, CP, and AdjP are rather hard to find. Moreover, the use of X-COMP and XADJ seems likely to occur in constructing headlines. But, not all of the headlines omit their subject, especially if the authors want to highlight the actors/agents.

\section{The Use of Oblique $\theta$}

Besides the use of X-COMP and XADJ, several headlines found using other functions of Governable Grammatical Functions, such as oblique tetha. It is found in passive voice. However, I would like to emphasize that not all of the passive voice use OBL $\theta$. We may assume that it occurs when the journalist focuses on the agent, the action is less important in this case. The examples of passive voice found in several Indonesian online newspaper headlines:

1. Marsekal Hadi Tjabjanto Disebut "Otak Setan" oleb Teman SMAnya

2. Seorang Perempuan Tewas di Tangsel Diduga Dibunuh Pacarnya
3. Mabuk dan Bikin Keributan, Seorang Satpam Tewas Dipukul Rekan Kerjanya

4. Di Indonesia Penelitiannya Ditolak, Siswa Yogya Diundang Google.

5. Ditangkap di Bandara Batam, Anwar bertelur sabu.

The underlined words refer to OBL $\theta$. It is the agent in the passive voice that may be omitted. The bold words refer to passive voice that has no OBL $\theta$ because it is eliminated. The choice of using it or not is rather to the semantic factor than to syntax. By showing the agent, it means the writers want to show the important role he/she has in the action described in the news article. If the agent is deleted, the highlight is on the action, no matter who the agent is. For instance, in number 4, why in the first passive voice it uses no agent, but in the second phrase, it uses oblique? If we read carefully, "Siswa Yogya Diundang Google" or a Yogya student is invited by Google, the writer wants to emphasize the agent. Google is a great company, so it will be so special if an ordinary student called by it. To sum up, the use of object in passive voice depends on the author's intention. The way he/she realizes it is by the role of syntax.

\section{CONCLUSION}

To sum up, LFG is useful when we not only analyze the structure of a sentence, but also its functional information. One of its applications is to analyze newspaper headlines. The syntactical structure of headlines is rather different to ordinary or daily sentences. It has some characteristics that make it simple, concise, and efficient to make the readers as the consumers attracted to buy or to read the whole news articles.

Some characteristics of Indonesian online newspaper headlines that the researcher summarizes from the analysis above are: (1) using X-COMP and X-ADJ to omit the subjects, especially in the complex words in order to make it simpler and easy to read; (2) the use of OBLO in 
passive voice to emphasize the agent; (3) if the writers want to highlight the action, not the agent, they do not use OBLO; (4) the use of transitive and intransitive verbs sometimes occur commutatively. Sometimes the intransitive becomes transitive, and it impacts the arguments used; (5) the most constructed phrases in the Indonesian headlines are IP, NP, and VP; (6) the verbs usually shortened (i.e menjadi - jadi, menuntut - tuntut), (7) the articles (seorang, sebuab) and not important words usually omitted.

Those characteristics may not be followed by journalist as many factors influence their writings. However, those characteristics can be the strategy of the journalists to construct their headlines efficient and effectively.

\section{REFERENCES}

Alamoudi, K. (2017). Syntactic Ambiguity of Arabic Prepositional Phrase Attachment in Saudi Newspaper Headlines. Arabic Language, Literature \& Culture, 2(1), 13-17. http://doi.org/: $\quad 10.11648 /$ j.allc. 20170201.14

Asudeh, A., \& Toivonen, I. (2009). LexicalFunctional Grammar. Corrected final draft to appear in Bernd Heine and Heiko Narrog, eds., The Oxford Handbook of Linguistic Analysis. Oxford: Oxford University Press.

Dalrymple, M. (2001). Lexical Functional Grammar. No. 34 in Syntax and Semantics Series. New York: Academic Press. Diakses dari: https://www.stanford.edu/group/na sslli/ courses/as-cr-da/apbooknasslli.pdf
Ehineni, T.O. (2014). A Syntactic Analysis of Lexical and Functional Heads in Nigerian English Newspaper Headlines. International Journal of Linguistics, 6(5).

Elmawati. (2013). Structural Ambiguity in the Headlines Compiled by Department of Languages, Cultures and Linguistics Bucknell University: A Study on the X-bar Theory. Lantern Journal on English Language, Culture and Literature), 2(3).

Kaplan R. M, \& Bresnan, J. (1982). LexicalFunctional Grammar: A Formal System for Grammatical Representation, in Joan Bresnan (ed). The Mental Representation of Grammatical Relations. Massachusetts: MIT Press.

Mozūraityte, R. (2015). Newspaper Style: Stylistic Features of the Headlines. Unpublished bachelor thesis. Department of Foreign Language Studies. Siauliai University.

Ogunsiji, M. A. (1989). An introduction to print journalism. Ikeja: Nelson Publishers.

Subiyanto, A. (2011). Motion-Direction Serial Verb Constructions in Javanese: A Lexical-Functional Approach. The article was presented in International Seminar Language Maintenance and Shift III. In. Jee Sun Nam, Agus Subiyanto, \& Nurhayati (eds), Diponegoro University, Semarang, Indonesia, pp.65-69.

Swan, M. (2005). Practical English in Usage. Oxford: Oxford University Press.

Tiono, N. (2003). An Analysis on Syntactic and Semantic Factors Found in Newspaper Headlines. K@Ta Academic Magazine, 5(1). 